\title{
Where is the avoidance in the implementation of wetland law and policy?
}

\author{
Shari Clare $\cdot$ Naomi Krogman $\cdot$ Lee Foote $\cdot$ \\ Nathan Lemphers
}

Received: 3 June 2010/ Accepted: 8 January 2011/Published online: 20 January 2011

(C) The Author(s) 2011. This article is published with open access at Springerlink.com

\begin{abstract}
Many jurisdictions in North America use a "mitigation sequence" to protect wetlands: First, avoid impacts; second, minimize unavoidable impacts; and third, compensate for irreducible impacts through the use of wetland restoration, enhancement, creation, or protection. Despite the continued reliance on this sequence in wetland decision-making, there is broad agreement among scholars, scientists, policymakers, regulators, and the regulated community that the first and most important step in the mitigation sequence, avoidance, is ignored more often than it is implemented. This paper draws on literature published between 1989 and 2010, as well as 33 semi-structured, key-informant interviews carried out in 2009 and 2010 with actors intimately involved with wetland policy in Alberta, Canada, to address key reasons why
\end{abstract}

\section{S. Clare $(\bowtie)$}

Department of Renewable Resources, University

of Alberta, Edmonton, AB, Canada

e-mail: sclare@ualberta.ca

\section{N. Krogman}

Department of Rural Economy, University of Alberta,

Edmonton, AB, Canada

\section{Foote}

Department of Renewable Resources, University of Alberta, Edmonton, AB, Canada

\section{N. Lemphers}

Pembina Institute, 219 - 19 Street NW, Calgary,

AB, Canada "avoidance" as a policy directive is seldom effective. Five key factors emerged from the literature, and were supported by interview data, as being central to the failure of decision-makers to prioritize wetland avoidance and minimization above compensation in the mitigation sequence: (1) a lack of agreement on what constitutes avoidance; (2) current approaches to landuse planning do not identify high-priority wetlands in advance of development; (3) wetlands are economically undervalued; (4) there is a "techno-arrogance" associated with wetland creation and restoration that results in increased wetland loss, and; (5) compensation requirements are inadequately enforced. Largely untested but proactive ways to re-institute avoidance as a workable option in wetland management include: watershed-based planning; comprehensive economic and social valuation of wetlands; and long-term citizen-based monitoring schemes.

Keywords Wetland · Policy - Avoidance · Mitigation · Compensation · Management · Loss · Watershed planning

\section{Introduction}

Many jurisdictions in North America use a "mitigation sequence" to protect wetlands: First, avoid impacts; second, minimize unavoidable impacts; and third, compensate for irreducible impacts through the use of wetland restoration, enhancement, creation, or 
protection. Despite the continued reliance on this sequence in wetland decision making, there is broad agreement among scholars, scientists, policymakers, regulators, and the regulated community that the first and most important step in the mitigation sequence, avoidance, is ignored more often than it is implemented (Burgin 2010; ELI 2009; Hough and Robertson 2009; Murphy et al. 2009a). While many studies have shown that compensatory laws and policies have not been effective in maintaining wetland area and function (for example, Spieles 2005; Cole and Shafer 2002; NRC 2001; Malakoff 1998; Roberts 1993; Zedler 1996), and often have unintended social impacts (see BenDor et al. 2008; BenDor et al. 2007; Ruhl and Salzman 2006), few explicate why these laws and policies have failed, or suggest alternative approaches to regulating and managing wetland impacts.

Toward that end, the key objective of this paper is to summarize research explaining why wetland avoidance is commonly overlooked in the permitting process, and to advance what we consider to be key policy modifications or alternatives to incentivize wetland avoidance as a workable alternative to compensation. By critically examining factors that influence wetland permitting decisions, improvements can be made to wetland law, regulation, and policy such that losses can be prevented, rather than following the heretofore pattern of permitting losses and hoping that compensation will replace lost wetland area, values, and functions.

While there are many countries worldwide that have made strides in wetland regulation, we have limited our examination of wetland law, regulation, and policy to the United States and Canada, and specifically the province of Alberta. As carried out in other environmental policy and conservation strategy evaluation studies (e.g., Reed 2008; Lovell and Sullivan 2006; Brooks et al. 2005), we conducted a web-based search of wetland management literature from peer-reviewed sources and widely available grey literature published between 1989 and 2010. Articles were located using search engines such as ISI Web of Knowledge, JSTOR, Web of Science, and Google Scholar, using keyword search terms such as: wetland, plan, success, assessment, avoidance, compensation. This work was also informed by 33 semistructured, key-informant interviews conducted in Alberta between 2009 and 2010. Key informants were asked questions about the effectiveness of the existing wetland policy and the sample consisted of regulators, agency decision-makers, scientists, industry representatives, and consultants who were intimately familiar with the policy. This sociological methodological approach has been applied previously in the evaluation of wetland policy implementation in Louisiana (Krogman 1999). Interviews were conducted until saturation was reached, i.e., no new arguments were advanced among respondents (Krogman 1996), and all interviews were recorded, transcribed, and coded across themes using the qualitative data analysis software program NVIVO.

\section{Background: wetland regulatory context}

\section{United States}

Wetland regulation has a long and complex history in the United States, going back to 1972 and the introduction of Section 404 of the Federal Water Pollution Control Act (more commonly known as the Clean Water Act). The principal intent of the Act was to "restore and maintain the biological, chemical, and physical integrity of the Nation's waters" in part through the establishment of the Section 404 permitting program. This regulatory process requires that an Individual Permit be issued for any activity that results in the discharge of dredged or fill materials into waters of the United States, including wetlands (Hough and Robertson 2009; Chertok and Sinding 2005; Williams and Connolly 2005). Both the Army Corps of Engineers (the Corps) and the Environmental Protection Agency (EPA) were given jurisdiction over the permit program, with the Corps being responsible for overseeing day-to-day permitting activities, and the EPA being given authority ("in conjunction with" the Corps) to develop guidelines for permit approvals, as well as the authority to override any permit approval issued by the Corps (Ellis 2005).

In 1977, amendments were made to the Clean Water Act that allowed the Corps to issue General Permits for activities that resulted in "only minimal adverse environmental harm". ${ }^{1}$ These General Permits lacked the more rigorous environmental oversight

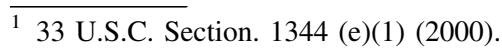


of Individual Permits (Hough and Robertson 2009; Taylor and Geoffroy 2005), and clearly signaled that the goal of restoring and maintaining the integrity of wetlands was not going to be achieved by simply denying permits and avoiding impacts. Consequently, other regulatory and policy mechanisms began to emerge, and the concept of "mitigating" the damage to wetlands through impact minimization or compensation began to gain traction as an alternative to wetland avoidance (Hough and Robertson 2009; Kruczynski 1990).

In 1980, the Section 404(b)(1) Guidelines were released, putting new restrictions on the discharge of dredged and fill materials and formalizing the concept of "sequencing" wetland permit decision-making. Under Section 230.10 (a-d) of the Guidelines, a permittee must demonstrate that there is no other available, feasible, or environmentally preferable alternative to the proposed project: the so-called least environmentally damaging practicable alternative (LEDPA) analysis (Pifher 2005). While these regulations formally prioritize wetland avoidance over impact minimization and compensation, permittees can argue that there are no other "practicable alternatives" to the proposed project by citing limitations presented by factors such as land ownership and availability, geographic scope, economic viability, logistics, and/or technological feasibility (Pifher 2005). Further, permittees can define their overall project purpose in a way that effectively makes alternatives to wetland loss impracticable; they can also argue that their project is "water dependent", or that alternative sites would result in less desirable environmental outcomes (Hough and Robertsen 2009; Pifher 2005). The Corps and the EPA have also acknowledged that there is a need for "flexibility" in the application of the alternatives analysis, given that impacts to wetlands may vary in their extent, severity, and duration (Pifher 2005). Combined, these factors have led to a general failure by both the Corps and EPA to strictly enforce the mitigation sequence as written in the 404(b)(1) Guidelines, and have arguably contributed to the creation of a regulatory culture where "mitigation" and "compensation" are generally seen as being one and the same (Hough and Robertson 2009).

The reliance on compensation over avoidance as a mechanism for achieving wetland management goals was reinforced in 1989, with the adoption of the "no net loss" policy by the Bush administration. While many felt that this new policy elevated the issue of wetland loss in the national consciousness, there was also a recognition that the no net loss goal "was not merely to be achieved through the denial of permits, or even the avoidance and minimization of impacts, but rather through allowing impacts and requiring compensation" (Hough and Robertson 2009, p. 26). As the use of wetland compensation grew throughout the 1990s, there was mounting pressure from industry to move away from on-site and in-kind wetland mitigation, and towards the use of wetland mitigation banking as a market mechanism that would allow for the increasing use of off-site compensation (Ruhl et al. 2009; Salzman and Ruhl 2005). This approach to wetland compensation was seen by government agencies to "ensure wetlands conservation at minimum economic and political cost" (Salzman and Ruhl 2005, p. 2), and by 2005 wetland banking had grown to account for as much as $30 \%$ of all mitigation being carried out in the US (Wilkinson and Thompson 2006). The increasing use of wetland banking as a form of permittee-responsible mitigation drove the need for clearer and more consistent standards and procedures. As a result, the Corps and the EPA jointly issued new rules for wetland mitigation in April of 2008. Though designed to improve compensation outcomes by creating clear performance standards and administrative procedures, concerns have emerged that the procedures outlined in the new rule will become yet another regulatory mechanism that further institutionalizes the use of compensation over avoidance (Stokstad 2008). Given that less than one percent of permits in the US are denied by the Corps (Murphy et al. 2009b), and the general assumption by proponents that they will not be denied a permit (Nichols 2008), it seems apparent that compensation, over avoidance or minimization, has become the preferred mechanism by which to achieve the goal of no net loss in the United States (Hough and Robertson 2009; Race and Fonseca 1996; Kruczynski 1990).

Alberta, Canada

Wetland management and regulation in Canada has a much shorter history than that of the United States, and wetland policy in many Canadian jurisdictions is either non-existent or is in early stages of 
development (Rubec and Hanson 2008). One exception to this is Alberta, where the trajectory of wetland policy can be said to resemble that of the United States, particularly with respect the growing trend towards the use of compensation over avoidance as a mechanism to meet wetlands policy goals.

In 1993, Alberta introduced a regional wetland policy that primarily applied to marsh wetlands in the settled areas of the province. While the stated policy goal is to "sustain the social, economic, and environmental benefits that functioning wetlands provide, now and in the future" (AWRC 1993), the implementation of the policy has focused on achieving a no net loss of wetland area through conserving wetlands in a natural state, mitigating the degradation or loss as close to the site as possible, and enhancing, restoring, or creating wetlands in areas where they have been depleted or degraded (Rubec and Hanson 2008; AWRC 1993). While Alberta was one of the first provinces in Canada to adopt a wetland policy, very little progress was made with respect to implementation of the policy until December of 1999, when the outdated Water Resources Act was replaced by the Water Act. This new legislation shifted the focus away from solely regulating the allocation of water, and instead included a more comprehensive purpose for supporting and promoting the "conservation and management of water, including the wise allocation and use of water". ${ }^{2}$ Under the Act, any activity that "causes, may cause or may become capable of causing an effect on the aquatic environment" ${ }^{3}$ requires an approval, and in making a decision about granting an approval, the government "may consider any existing, potential or cumulative effects on the aquatic environment". Notwithstanding this more conservation-oriented language, the Purpose of the Act also specifies that decisions about the management of water resources must also recognize "the need for Alberta's economic growth and prosperity". 5

As in the United States, the mitigation sequence has been used to help inform and direct wetland decision-making in Alberta, and outcomes have been

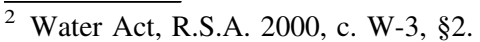

3 Water Act, R.S.A. 2000, c. W-3, §1(1)(b)(i)(D).

${ }^{4}$ Water Act, R.S.A. 2000, c. W-3, §38(2)(b)(i).

5 Water Act, R.S.A. 2000, c. W-3, §2(b).
}

similar with respect to a pervasive tendency to skip over any serious consideration of wetland avoidance, and to instead move immediately to compensation for wetland loss. One of the most significant differences between these jurisdictions in their approach to wetland regulation, however, is that Alberta has no equivalent process to the alternatives analysis, and no formal process for defining the basic project purpose. Once a proponent enters the permitting process, there is often very little consideration given to whether there are alternatives to the proposed project location, as expressed by one government approval writer who said:

What we found is that avoidance just doesn't seem to be an option for most of [the permit applicants] out there. They've already planned their project; they know what they want to do. It's very difficult to work around that. (Approval writer, personal communication, June 2009)

In fact, many policy actors in Alberta feel that wetland avoidance is simply not a practical option in light of other considerations, such as economics. There is often an acceptance that there is no alternative to filling the wetland and simply compensating for the loss, as summarized by another government approval writer who said:

We would want you to avoid the impact whenever and wherever possible, but there is a realization that it's not practical and development will occur, and so then we have to go to minimize, mitigate, and compensate. (Approval writer, personal communication, August 2009)

The general failure to avoid wetland impacts in both the US and in Alberta, despite this preference being stated in regulation and policy, has led to an overall decline in the number and quality of natural wetlands in many jurisdictions across North America (Dahl and Watmough 2007; Walters and Shrubsole 2005; Zedler and Kercher 2005). It has also spurred a lively debate over whether the mitigation sequence of avoid, minimize, and compensate is an effective approach for managing wetland habitats within a no net loss framework. For example, Burgin (2010) suggests that "the outcome for wetland mitigation may not be an 'unmitigated disaster' but it is, at best, modestly successful" (p. 53), and Murphy et al. (2009b) go so far as to say that "mitigation activities 
continue what can only be described as a 'cockeyed optimist' approach to aquatic resources permittingone that is destined to lead to further deterioration of the nation's aquatic resource base" (p. 3112). Given that many jurisdictions have adopted the mitigation sequence as a means to achieve a no net loss of wetlands, it is critical that we begin to better understand the key factors that lead to the pervasive tendency to skip-over avoidance.

\section{Key failures in the avoidance of wetlands}

Five key factors emerged from the literature, and were supported by interview data, as being central to the failure of decision-makers to prioritize wetland avoidance and minimization above compensation in the mitigation sequence:

1) A lack of agreement on what constitutes "avoidance";

2) Current approaches to land use planning do not identify and prioritize wetlands in advance of development;

3) Wetlands are economically undervalued;

4) A "techno-arrogance" is associated with wetland creation and restoration, resulting in increased wetland loss;

5) Requirements for compensation are inadequately enforced.

A lack of agreement on what constitutes

"avoidance"

Foremost on the list of problems associated with the wetland mitigation sequence is the absence of a clear understanding on what constitutes "avoidance", and a lack of standardized methods or guidelines for evaluating or interpreting this regulatory requirement (ELI 2009; Yocom et al. 1989). While the regulatory understanding around wetland mitigation in the US has historically included a sequencing of "avoid, minimize, and compensate", these words were never expressly written into US regulation until the Final Rule on Compensatory Mitigation for Losses of Aquatic Resources was issued in April of 2008. Prior to that, the concept of wetland mitigation was only vaguely defined as a sequence of decisions that make up the alternatives analysis, which was further clarified in a Memorandum of Agreement between the Corps and the EPA in 1990. A critical component of the alternatives analysis is how the proponent has defined the basic project purpose, and whether the regulator accepts the project purpose as presented. While the regulator is not obligated to accept the basic project purpose as proposed by the permittee, this step alone has the potential to foreclose on any opportunity to avoid wetland impacts; if the purpose has been too narrowly defined, alternatives may be considered impracticable (Pifher 2005). The language that allows compensation if avoidance or minimization "is not practicable" becomes a de facto loophole in its non-specificity, allowing developers to skirt the intent of the law and move directly to compensation. Given that there is no rigorous and repeatable process under which to consider "practicability" (Murphy et al. 2009a), the availability of options other than avoidance, such as compensation, are too easily considered by regulators. For example, in the US, Krogman (1999) found that administrative momentum, or the implicit assumption that regulators need to find a way to make it work for the applicant, makes asking the permit applicant to consider other sites for development seemingly unreasonable.

Once there is agreement on the basic project purpose and the proponent has demonstrated there is no other practicable alternative in terms of project location, there is still a requirement under Section 230.10 of the 404(b)(1) Guidelines to make the on-site impacts to the wetland as small and innocuous as possible, including giving consideration to how the project can be designed to avoid or minimize impacts (Hough and Robertson 2009). In this step there is additional confusion over the meaning of avoidance; to some regulators on-site avoidance means preventing direct impacts, such as placing fill material directly into a wetland. To other regulators, "an attempt constitutes avoidance" (ELI 2009, p. 3), meaning that any effort to modify a project—regardless of whether the project ultimately results in a direct impact-is considered avoidance. The language around the "minimization" of wetland impacts is also sufficiently vague, and in many cases, avoidance and minimization are lumped together such that "any measures to reduce impacts usually are applied to satisfy both requirements" (ELI 2009, p. 6).

Given that Alberta does not have a formal process to examine alternatives to the project location, most 
of the consideration for avoidance and minimization is given to project design, and many regulators have indicated that they lack clear guidance on when to deny permits on the grounds that the applicant has not demonstrated wetland avoidance on-site. This was expressed by one wetland approval writer who commented:

[The mitigation sequence] is more of a mechanism for enabling [wetlands] to be disturbed. We don't really have a good mechanism of saying, 'When should we say no?' If you have a sensitive vegetation species, should we be saying no? If there's sensitive wildlife, should it be no? We don't have clear guidelines on that. (Approval writer, personal communication, August 2009)

Given the lack of clarity around what constitutes avoidance and minimization, in addition to an absence of clear standards or guidelines, wetland permit decisions in both the US and Alberta are subject to a high degree of subjective interpretation by regulators. This leads to an approval process that is characterized by inconsistent decision-making and uncertainty within and between jurisdictions (ELI 2009). In Alberta, one regulator is quoted as saying:

Consistency is an issue... and personally, I think it looks bad in the department. We should [have] a standard approach. Maybe you have different flavors from different offices, but the requirement... and the expectations should be the same across the board (Approval writer, personal communication, August 2009)

Some government agencies also consider their role to be about managing for development, rather than conserving or protecting wetland resources (Krogman 1996, 1999). For example, one regulator from the United States was quoted as saying, "Let's be real, this is not a prevention program, it is a regulatory program" (ELI 2009, p. 3). Such attitudes lead to more permissive application processes where regulators rarely deny approvals (Hough and Robertson 2009; Murphy et al. 2009 b), but rather work together with applicants to achieve the applicant's desired outcome. For instance, one wetland approval writer in Alberta said:

Well, there's always the ability to say no. Do we say no very often? Not really. What we try to achieve is the best outcome. (Approval writer, personal communication, June 2009)

In most cases, the "best outcome" does not include the avoidance of wetland impacts, but rather, approval of development plans and permit conditions that are palatable and acceptable to the applicant, which most often includes wetland compensation (Nichols 2008).

Poor planning in advance of development

Failure to identify, recognize, and specifically designate wetlands or wetland communities that should be prioritized for conservation, protection, or restoration enables continued incremental losses of wetland area and function at both local and regional scales (Brody and Highfield 2005). Indeed, LaPeyre et al. (2001) found that states with a wetland management plan understand their resources and relevant actions for management better than states lacking a wetland management plan. More comprehensive land use planning that identifies high priority wetlands would allow land managers, developers, and individual landholders to make more informed decisions about land acquisition, and gives them the ability to weigh the potential benefits and costs associated with development. Designating ecologically significant wetlands in advance of development would allow for the avoidance of high priority sites, thereby connecting larger regional management goals (and ecological function), with site-by-site permitting decisions. Brody and Highfield (2005) argue, for example:

A clear understanding of the adverse impacts caused by urban development and resource degradation can assist planners in mitigating loss of ecosystem structure and function. When incorporated into a planning process and final plan, this information communicates the importance of protecting wetland function and integrity at the watershed level (p. 173).

From the perspective of land developers, better regional planning and prioritization of high-value wetlands provides increased certainty and decreases risks associated with the existing permitting process. For example, a senior executive in a land development company in Alberta indicated that improved watershed planning would be an additional tool that could be used to help evaluate future projects, and: 
If there [are] areas of wetlands that are significant, well then if we know that up front, we wouldn't go out and purchase them and try to develop them. (Sr. Executive, Land Development Company, personal communication, June 2009)

This sentiment was echoed by a government employee who said:

I think the [wetland protection and conservation] debate needs to be taken up to a land use discussion to talk about what areas of wetlands do we want to preserve? Where should we keep them, where should we not? Where is it okay to develop, where is it not? It's a broader context, and I find that our [wetland approval] process tends to get leveraged a little bit in those discussions. (Approval writer, personal communication, August 2009)

Despite the existence of available technologies to assist in the prioritization of wetlands for protection, such as GIS-based synoptic land cover maps, rapid ground-based assessments, and intensive field assessments (Brooks et al. 2004), many land use planners do not prioritize significant wetlands or wetland communities. The failure to prioritize is often due to limited wetland mapping, inadequate wetland assessment methodologies, and poor linkages between wetland management actions and outcomes (LaPeyre et al. 2001). The result is that rare, unique, or highvalue wetlands are treated with the same regard as common or low-quality wetlands, and few barriers to their loss have been brought to bear, contributing to persistent and incremental losses of wetlands. Murphy et al. (2009a) concurs, suggesting that even new and stricter rules that favor wetland avoidance in the United States "allow for a project-by-project analysis of mitigation that need not look at the entire watershed and its needs" (p. 15).

Ambiguous and competing goals within and between government agencies can also contribute to the lack of prioritization and planning in wetland regulation and management at various scales. Without clear goals for maintaining wetland ecosystem function or protecting wetlands that are highly valued socially, simple rules of minimizing harm and tradingoff one wetland for another has become the norm (Mann and Goldman-Carter 2008; Ehrenfeld 2000).
An Alberta example of this shows that land use planning and regulatory decisions are made at different scales by multiple governments and agencies, including: municipalities for land-use zoning and bylaws; Alberta Energy for mineral rights; Alberta Sustainable Resource Development for forest resources and public lands; Alberta Environment for water and air; and Fisheries and Oceans Canada for fish and fish habitat. To further complicate matters, wetland policy implementation varies between the white zone (the southern one third of the province that is mostly private land and dominated by agricultural land use) where wetland impacts are regulated by an interim wetland policy, and the green zone (the northern two thirds of province comprised primarily of publicly owned forested lands) where the interim policy does not currently apply. This fragmentation of decision-making and general failure to better integrate planning at multiple scales has contributed to the ineffectiveness of the wetland policy in Alberta.

Divergent goals for wetland management can also occur between regulators and restoration service providers (ELI 2006). In this case, the intention of (or task assigned to) the restoration service provider is to meet a specified goal or set of minimum criteria to ensure, for example, a no net loss of wetland area, even if the compensatory wetland is not of the same replacement value as the wetland that was lost. Indeed, many in-lieu fee programs in both Alberta (personal communication, August 2009) and the US (ELI 2006) allow restoration service providers to accept wetland compensation funds before mitigation sites are even identified or secured. There are also concerns in Alberta that without more coordinated planning, wetlands that have been restored or avoided will remain vulnerable to future incursions, particularly in areas where adjacent land values rise substantially, as they have in the more urbanized southern portion of the province and in northeastern Alberta where oil sands production is the dominant industry.

Reconciling this pluralism of goals at multiple scales of planning is a significant challenge in the management of wetlands across jurisdictions, and has been described by Huppes and Midden (1991) as a great social dilemma in wetland policy. Finding a balance between site-specific decision-making that focuses on the management of a single wetland, versus adopting a broader and more regional approach to wetland permit decisions, requires a fundamental (and 
likely structural) change in how wetlands are regulated. As Huppes and Midden (1991) suggest, "it is not so much individual projects that have to be improved, on an ad-hoc basis, but the overall development strategy" (p. 204); thus, the current approach in the US and Alberta of simply focusing on wetland impacts, permitting, and compensation at the project-level needs to be re-evaluated. Providing more clarity around the most appropriate scale (or scales) at which the alternatives analysis, and thus avoidance, should be applied would go a long way in resolving some of these issues in the US. In Alberta, the introduction of regulation that requires both a site-specific and a regional evaluation of impacts would contribute towards a more ecologically relevant approach to wetland management.

As a caveat, land use planning at the watershed level is not an answer in and of itself for integrating broader wetland values into permitting decisions. Throughout the land use planning literature are examples of plans and policies that have been adopted with little or no attempt to measure progress toward achieving stated goals and objectives (Wenig 2006; Seasons 2003; Baer 1997). Brody and Highfield (2005) summarized a host of studies and concluded that far more effort is put into planning than is accorded to the details of implementation. Similarly, in Alberta, there have been a number of elaborate land use planning efforts that have not resulted in measurable land use changes, such as new regulations and prioritized land uses (Wenig 2010; Fluet and Krogman 2009). Following through with effective implementation of land use planning and wetland prioritization is as important as the process of planning itself, and requires sufficient allocation of resources (e.g., financial and personnel) to be successful.

Wetlands are economically undervalued

The inexorable demand for developable land has resulted in the emergence of market-based mechanisms that have re-focused the discussion away from avoiding and minimizing wetland impacts, towards a more permissive orientation that allows for the "exchange" of wetland area or function between impact and compensation sites. The emergence of wetland banking and in-lieu fee payments has, in part, been driven by the perception that wetland avoidance in areas of economic conflict, such as residential subdivisions, is impracticable because the "assumed" value of wetlands is often much lower than the more immediate and tangible wealth generated by development. While accounting tools for ecosystem services do exist, they are complex (Moeltner and Woodward 2009) and are employed by relatively few specialized resource economists; consequently, the substantial economic value that flows from wetlands in the form of ecosystem goods and services (Moeltner and Woodward 2009; Costanza et al. 2008; Birol and Cox 2007; Boyer and Polasky 2004; Turner et al. 2000; Mitsch and Wilson 1996) is rarely considered in the permitting process.

Increasingly, off-site wetland exchanges are favoured by permittees because they are seen as being faster, easier, and more cost-effective than avoidance. The use of off-site compensation mechanisms also allows land developers to pass on the liability for meeting permit conditions for compensation to a third party, such as a wetland broker or restoration agency. It is for these reasons that the use of in-lieu fee payments in Alberta has increased substantially over the last 5 years, as articulated by one government regulator who said:

You really have to dig at the avoidance and mitigation piece...a lot of proponents, especially in the land development side of things, they just want to skip right to, "Let's write a cheque". (Approval writer, personal communication, August 2009)

This approach to simply "bundling" wetland functions and services and exchanging them across long distances has led to wetlands being "abstracted from their place-specificity" (Robertson 2000, p. 478), and has resulted in broad changes in the distribution, type, size, quality, and connectivity of wetlands. For example, in many cases we have observed in Alberta, wetlands have been replaced out-of-kind (i.e., not typefor-type), and many small wetlands have been replaced by a single large wetland, often in a different watershed. Further, decisions about where to locate compensation sites in Alberta are rarely driven by ecological criteria, but are instead influenced heavily by land availability, as articulated by a wetland restoration agency employee who said:

The controlling factor for wetlands in the province, even though the water is provincial 
jurisdiction, [is that] the ownership of that land is private...if you could just go out and rebuild [wetlands] wherever you wanted it'd be real easy to do, but unfortunately they have to have approval from those landowners. (Wetland restoration agency employee, personal communication, August 2009)

Robertson and Hayden (2008) have also reported a trend in the Chicago region where mitigation banks are frequently located in areas where land value prices are considerably lower than at the site of impact. This arguably creates a large subsidy for industry and land developers who are able to buy credits in a wetland bank for far less money than they receive when their product is sold in the marketplace. While private interests gain considerably in this arrangement, the public largely pays this subsidy in the form of lost ecosystem goods and services (de Groot et al. 2010; Mitsch and Gosselink 2000), and there are often unanticipated social costs associated with the redistribution of wetlands through the use of compensation (BenDor et al. 2008; BenDor et al. 2007).

The reliance on wetland banking or in-lieu fee payments as a mechanism to replace wetlands assumes that the values, functions, and services provided by the compensatory wetland are in some way equivalent to those that were lost, and are thus fungible (items freely interchangeable with another to satisfy an obligation). Where wetlands are assumed to be fungible, trade in these wetlands grows and the demand for comparability emerges. In Alberta, all of the government regulators we interviewed indicated that the most common metric used for comparability or equivalency between impacted and compensatory wetlands is area, with very little consideration given to wetland functions or services. Wetlands have thus become a commodity in a market where the measure of comparability between the items being exchanged disregards ecological and social values and functions. As many other scholars have argued, wetlands vary considerably in their value and function by type, landscape context, and spatial scale (de Groot et al. 2010; Hein et al. 2006; Mitsch and Gosselink 2000); therefore, it is difficult to meet the goal of maintaining the biological, physical, and chemical integrity of wetlands in a market where area is the only criteria used to assess comparability.
"Techno-arrogance" associated with wetland creation and restoration results in increased wetland loss

The term "techno-arrogance" has been used by other scholars to describe humankind's approach to using technology to "solve" problems in the natural world, such as climate change, alien species invasions, or toxic pollutants, which have come about through anthropogenic activities (Meffe 1992; Ehrenfeld 1981). This thinking aptly characterizes the emerging industry of wetland creation and restoration in North America. Underlying the notion that wetlands can be "created" is an implicit "faith" that with sufficient money, engineering, heavy equipment, and selection of materials, a wetland can be designed to fully mimic the values of a natural system as if it were a simple piece of machinery. In Alberta, there has been increasing pressure for the government to accept naturalized storm water management facilities (NSWMF) as complete or partial compensation for the loss of natural wetlands in urban growth areas. While these facilities are highly engineered and require continuous maintenance, many proponents argue that NSWMF are of higher quality than the wetlands they are replacing, as expressed by one land developer who said:

We have to come up with a new scenario where we actually can recreate [the wetland]. The outline of that wetland is the same as it is in a natural state, but it'll be in an urban environment and fed [by] storm water through a pipe, and it'll be much better, at least aesthetically, than it is today. ( $\mathrm{Sr}$. Executive of a land development company, personal communication, August 2009)

The idea that a constructed wetland that visually resembles a natural wetland is adequate compensation ignores that wetlands grow and develop according to a myriad of highly variable inputs over time, including stochastic weather, random arrival events of species, competition, surface and groundwater interactions, and many others. The fluctuations and interactions of wetland ecosystems are more akin to human metabolism than they are to an automotive engine, with dynamic interacting components such as wetland soils, hydrologic regimes, riparian zones, and water chemistry that are linked to their surroundings. Constructed wetlands must grow, mature, and evolve, 
often requiring decades to centuries to stabilize and broadly resemble naturally occurring wetlands. Such time frames are rarely considered in the price of compensation.

Despite the complexity of wetland ecosystems, optimistic and naive land developers, economists, engineers, and policy makers often argue for compensation over avoidance, confident in the notion that constructed wetlands can adequately replace the values and functions of a natural wetland. The lack of focus on wetland avoidance allows for engineered compensatory wetlands to receive more political and economic value than their natural counterparts, as they provide decision-makers the options, flexibility, and negotiation room beyond a hard and fast requirement to relocate the proposed development to a nonwetland site. The premise of compensatory offset wetland policies is that habitat loss can be mitigated through the creation or restoration of habitat that is equivalent to that which was lost. The challenges associated with measuring, let alone reproducing, the full suite of ecological, social, and economic values and functions of a natural wetland makes the reliance on this policy approach untenable in all cases, and highlights the need to give greater consideration to avoidance in the mitigation sequence.

Inadequate enforcement and compliance of wetland law and policy

Enforcement and compliance are key components to the success of any wetland regulatory program. The focus of enforcement action is on preventing "frontend" violations; that is, ensuring that wetlands are not filled without first securing a government permit or approval. For many wetland programs, ensuring that a permit has been issued prior to the loss of a wetland is a difficult task, as illustrated by a Massachusetts study that found more than $50 \%$ of the acres filled in 2001 were "illegal or likely illegal" and occurred without a permit (MDWM 2008, p. 15). The problem of illegal wetland filling is certainly not unique to Massachusetts; in Alberta, an environmental consultant we interviewed estimated that up to twenty percent of their clients had impacted a wetland prior to securing an approval (Sr. Environmental Scientist, personal communication, July 2009). Many in Alberta feel that this failure is due primarily to ignorance about the law and confusion over private versus public property rights, as articulated by one government employee who said:

There is a large segment of the [agricultural] producer population that doesn't understand that bodies of water are crown land. [The wetland is] on their land, it's surrounded by [their land] - it must be theirs. (Alberta Government employee, personal communication, May 2010)

While there are clearly enforcement problems in many jurisdictions, there is also a growing need for "back-end" monitoring to ensure that compensation sites are performing adequately and are meeting the conditions set out in the permit. The list of studies documenting non-compliance in the United States is long (for example, see Reiss et al. 2009; Brown and Veneman 2001; Turner et al. 2001; Zedler and Callaway 1999), and clearly articulate the general failure of permit holders to replace wetland functions through off-site compensation (Burgin 2010; Cole and Shafer 2002; Malakoff 1998; Roberts 1993; Spieles 2005; Zedler 1996). The lack of government oversight to follow-up and ensure that the conditions of approvals for wetland losses are met over an appropriate timeframe reinforces the preference for compensation over avoidance; if permit holders are not held accountable, then compensation is much easier and economical than avoidance.

There are many recorded failures to meet the ecological conditions stipulated in wetland permits, yet few studies have examined why regulatory compliance has been so weak. One such study, conducted by the United States Government Accountability Office (GAO 2005), highlighted a number of major shortcomings of the regulatory process, including a general reluctance by the regulators to sanction violators, preferring instead to rely on negotiation to resolve the contravention. In many cases, legal recourse for non-compliance was not an option, as the conditions of the permits were not specific enough to allow for enforcement action against the violator, harkening back to the simple and vague language mentioned earlier.

In Alberta, an Auditor General's report released in 2010 criticized the government for its failure to adequately follow-up on wetland approvals to ensure that wetland compensation requirements were being met, and insisted that "[the Department of] 
Environment needs stronger systems to ensure that ... approval holders comply with the conditions in their authorizations" (AGA 2010, p. 55). The lack of followup action appears to be related to the administrative structure of the compliance and enforcement program, in which staff are primarily focused on responding to violations that come to the attention of the government through public complaints or self-reporting (Environmental Protection Officer, personal communication, July 2009). Further, Department of Environment efforts are focused almost entirely on enforcement action for violations that occur without an approval, rather than sanctioning proponents who violate the conditions of an existing approval; once an approval for a wetland impact has been issued there is very little credible threat of sanction for non-compliance. As one government approval writer pointed out:

The department is really good at issuing the approvals and doing the up-front work ... we're not as good as following up with the monitoring and the back-end stuff, just because you get busy with the next project. There's always something coming up, the next fire to manage. (Approval writer, personal communication, August 2009)

This reactive, rather than proactive, approach to wetland regulation in Alberta appears to be related, at least in part, to a lack of government capacity and resources, as expressed by another approval writer who said:

I think we need to be more proactive, and probably any person that you talk to would agree with that statement - that the government needs to be proactive, but it's a matter of resources ... it's pretty obvious to me that we're somewhat understaffed in terms of our ability to deal with some of these approval situations, and probably even more so in the enforcement and compliance end of things where we just don't have the capacity to be proactive. We're a reactive organization right now. (Approval writer, personal communication, June 2009)

Some authorities claim that increased oversight by regulatory agencies, such as more frequent interaction with permit holders, regular site visits, and more frequent enforcement actions, could improve compliance outcomes (Reiss et al. 2009; Schulte-Hostedde et al. 2007; NRC 2001). More rigorous record keeping (Minns et al. 1996; Kentula et al. 1992) and better coordination of policy within and between jurisdictions and agencies responsible for wetland permitting (Austen and Hanson 2007; Race and Fonseca 1996) have also been suggested as a means for achieving better compliance. By improving compliance, not only would outcomes for compensatory habitat creation be improved, it may act as an adequate deterrent if the costs associated with meeting compensation requirements outweighed those of avoiding the wetland in the first place.

\section{Alternatives to address key failures in wetland avoidance}

To address the key failures in wetland avoidance described above, we recommend experimenting with a suite of policy tools, some of which are already in place in select jurisdictions, which would better link avoidance mechanisms with land use planning and regulation. Below we provide some thoughtful, though mostly untested, considerations for re-instituting avoidance as a workable option in wetland management, including: watershed-based planning; more comprehensive economic and social valuation of wetlands; and long-term citizen-based monitoring schemes.

Watershed-based planning

Watershed planning can provide an ecologically relevant alternative to the current piece-meal and compensation-focused approach to land use planning. The National Research Council report (2001, p. 4) on wetland losses concluded that:

A preference for on-site or in-kind mitigation should not be automatic, but should follow from an analytically based assessment of the wetland needs in the watershed and the potential for the compensatory wetland to persist over time.

By placing wetlands within a broader landscape context, watershed planning can help to prioritize the conservation of high value wetlands, or identify land uses that may not be compatible with regional wetland conservation goals (Chavan et al. 2008; Brooks et al. 2006; Stein and Ambrose 1998). Using scienceinformed watershed plans, wetlands can be managed within a larger hydrologic and ecologic regime that 
considers issues of water quantity and quality, habitat connectivity, and biodiversity in all of its complexity (NRC 2001; Margules and Pressey 2000).

A powerful science-based decision support tool that can be utilized for conservation planning at the watershed scale is systematic conservation planning (SCP). Systematic conservation planning is a rigorous, transparent, and repeatable framework that attempts to reduce the "uninformed opportunism" of traditional conservation planning by integrating multiple criteria (e.g., ecological, sociopolitical, economic) into broader landscape planning and decision-making (Pressey and Bottrill 2008; Sarkar et al. 2006; Margules and Pressey 2000). The framework for systematic conservation planning generally consists of several key steps (Groves 2003; Margules and Pressey 2000): setting conservation goals; identification of conservation criteria; development of a conservation strategy; identification of conservation areas; implementation and prioritization; and finally, monitoring and management. By utilizing this framework and systematically identifying wetland conservation criteria - the elements of biological and physical diversity that will be the focus of planning efforts - meaningful conservation goals can be set within a watershed, and priorities for wetland conservation, protection, or alternative management approaches can be identified in advance of development.

One key strength of SCP is the potential to involve local resource users and other key social actors at various stages in the process, including setting conservation goals, developing criteria and management strategies, and monitoring outcomes (Sarkar et al. 2006; Pierce et al. 2005; Cowling and Pressey 2003). Through SCP, local and regional conservation plans can be tailored to reflect the local context, allowing for the inclusion of a wide variety of perspectives and values in the planning process. The resulting user-friendly and target-driven planning tools that are the products of SCP can be used by authorities at various jurisdictional levels, from municipal to regional, to help inform land use planning and decision-making (Pierce et al. 2005). Wetlands can thus be framed in both time and place by iteratively and adaptively identifying future land use pressures and potential risks, thereby allowing for a greater emphasis being placed on the avoidance of wetlands that have been identified as being highpriority for management.
More comprehensive watershed-based planning also allows for the development and use of regionspecific wetland functionality indicators that can be derived through the use of benchmark or reference sites. Matthews and Endress (2008) suggested that the use of benchmarks could help agencies with permit approvals, selection of mitigation site locations, calculation of compensation ratios, development of performance criteria, and implementation of postconstruction monitoring protocols. Bedford (1999) argued that wetland restoration will be more successful if individual wetland restoration decisions are made in light of past and present regional profiles, and Olsen and Christie (2000) highlighted the importance of locally and socially relevant indicators to build local ownership of coastal (wetland) management, especially for direct users/abutters of wetlands. Watershed planning can also provide rich opportunities for more place-based and prescriptive restoration goals (Stanturf et al. 2001; Olsen and Christie 2000), thereby addressing some of the competing goals (individual to structural) that limit overall restoration effectiveness.

As landscape-level approaches to wetland management replace previous command-and-control style regulations, planners among different levels of government will need to coordinate carefully (BenDor and Doyle 2010), particularly in areas where watershed plans cross jurisdictional boundaries. The coordination required for watershed management can help clarify jurisdictional issues and uncertainties (ELI 2009), and improve interagency communication (Olsen and Christie 2000). While BenDor et al. (2007) found tension between local authorities as watershed-based management proponents, such tension was not necessarily disadvantageous, as it provided an avenue to help local and extra-local stakeholders more clearly articulate goals for restoration projects. Ehrenfeld (2000, p. 2) acknowledged such tension as an important component of projects because it "sets expectations, drives the detailed plans for actions, and determines the kind and extent of post-project monitoring".

Globally, climate change poses considerable threats to wetlands due to forecasted changes in hydrological regimes (Johnson et al. 2010; Acreman et al. 2009). As climate change planning is increasingly incorporated into natural resource management, watershed-based planning offers an 
effective mechanism in which to accommodate the impacts of climate change on wetlands (Erwin 2009; Simenstad et al. 2006). In certain parts of the world where climate change begins to negatively impact water resources, the water storage, filtration, carbon sequestration, biodiversity maintenance, and other ecological goods and services offered by wetlands will become increasingly valuable. Thus, watershed planning will allow for more accurate assessments of a region's vulnerability to climate change-related risks, such as drought (Hurd et al. 1999), and will be an important tool for assigning priority for the management of high-value wetlands.

In making this recommendation we acknowledge that this approach is not novel, and has previously been applied in some jurisdictions in one form or another, with varying degrees of success. For example, the US Environmental Protection Agency has an Advanced Identification (ADID) planning program that identifies wetlands that are "suitable or unsuitable for the discharge of dredged and fill materials", with the intent of providing local communities with "information to help them better understand the values and functions of wetlands in their areas" (EPA 2009). While this approach has merit, the program is not widespread and is not mandatory; thus, it is likely of limited use in planning and management at large scales. The concept of watershed planning also confronts tensions over the management of common pool resources on private property. This conflict is very real and presents itself as a significant challenge in the development and implementation of any watershed plan. For example, Ando and Getzner (2006) examined the role of land ownership in wetland conservation decisions in Australia, and found that wetlands were more likely to be protected on public versus private lands, and concluded "ownership status is a significant factor in the pattern of wetland conservation" (p. 302). While land ownership issues are a barrier to watershed-level planning and conservation, there is an emergence of new policy tools that may offer some opportunities in this regard, including biodiversity off-sets (ten Kate et al. 2004), transfer of development credits (Pruetz 2009), and reverse auctions (Packman 2010), to name only a few. Whether these tools are able to overcome the challenges of managing wetlands on private property remains to be seen.
More comprehensive ecological and social valuation of wetlands

Making informed decisions about the economic trade-offs associated with a given permit application are difficult for both developers and wetland regulators because the ecological, social, and economic values of wetlands are difficult to identify, combine, compare, value, and aggregate, resulting in a chronic undervaluation of wetland habitats (Costanza et al. 2008; Carlsson et al. 2003; Turner et al. 2000). Under current accounting practices and market orientation, the economic value of land adjacent to a wetland often exceeds the "assumed" value of the wetland itself, which leads to the belief that wetland avoidance is an impracticable economic option. This tendency to perceive wetlands as economic liabilities may be overcome if ecosystem services and social values were accounted for in permit and planning processes. Incorporating economic and social valuation processes into wetland permit approvals may help link the desired ecosystem goods and services to benefit cost analyses of areas being considered for development. In turn, increased economic values attached to those broader ecosystem and other nonmarket services (e.g., aesthetics, recreation, education) may provide disincentives to wetland development and help to focus development in non-wetland areas. By including environmental and social considerations in the accounting standards under which wetland regulators and land developers make their decisions, the notion of wetland compensation takes on a new meaning. It becomes much more costly to compensate for wetlands loss when the "true cost" of that loss is borne by the permittee, rather than the public.

Long-term citizen-based monitoring schemes

One of the reasons identified for the policy failure of wetland avoidance is inadequate enforcement of compensation requirements. This lack of enforcement can occur because of shrinking budgets for enforcement personnel, or it may be due to a deficiency in the quality or quantity of information available to enforce regulations, such as inadequate assessment or monitoring data. If wetland regulators do not have reliable data on the performance of natural, reclaimed, or constructed wetlands, it becomes very 
difficult to make evidence-based land use planning decisions. At the same time, environmental policy in North America is experiencing a move away from command-and-control style management towards self-enforcing market-based policies (Daley 2007), and increasingly towards resilience management such as adaptive co-management, networked, or collaborative environmental governance (Armitage 2008; Reed 2008).

One type of program that has strong potential in this emergent policy space is the use of long-term, citizen-based monitoring schemes to help manage local wetlands. These schemes would not only encourage local stewardship of wetlands, but would also provide data to help regulators gauge approval compliance, potentially resulting in improved environmental outcomes. For example, citizens have been trained to identify functional and structural characteristics of wetlands, and report on these measures in a consistent, reliable manner, at low cost to local institutions (Koontz and Thomas 2006). Inherent to this program might be an empirical expression of human valuation and appreciation for the wetlands, giving greater opportunity to measure the intangible social value of these habitats. With this new data and more engaged local citizens, it is more likely that wetlands will be avoided during development, as compared to decisions that are made in the absence of data and a locally organized wetland group. The inadvertent creation of local political will and interest in wetlands may be an antidote to public apathy, resulting in more careful scrutiny of development plans and the elevation of avoidance as the key policy activity for wetlands protection.

While the use of citizen scientists is a relatively recent phenomenon, citizens are increasingly being included in conservation and restoration planning (Currin et al. 2008; Oscarson and Calhoun 2007) and have been found to be effective assistants to local land managers (Sharpe and Conrad 2006). If a standard protocol is used (e.g., Christmas Bird Count), a diverse public can be used as a local resource that is capable of collecting data on both wetland structure and function (Currin et al. 2008). By utilizing citizen participation, not only are costs lowered compared to traditional data collection methods, but local stewardship is also promoted, with local communities benefiting directly from the educational value of participation (Hudson 2001).
The outcome may be a more engaged and informed citizenry that can bring political pressure to bear on the issues of wetland conservation, making wetland avoidance a more practicable option from a sociopolitical perspective. For example, Meyer and Konisky (2007) found that local environmental institutions that have included a broad array of community-based efforts to increase local participation in environmental decision making, particularly though local bylaws that protect wetlands, outperform jurisdictions that lack similar bylaws on numerous wetland measures.

\section{Conclusions}

Wetland avoidance needs to be reinstituted as the first, and most preferred option for wetland management in jurisdictions that utilize the mitigation hierarchy. While there is recognition in the literature that wetland avoidance is not practicable in all circumstances, there is overwhelming consensus that in order to meet wetland management goals, more emphasis needs to be placed on avoidance. Government decision-making is highly influenced by the subjective and ill-defined notion of balancing development and the environment; hence, governments are often fraught with a permissive orientation that makes avoidance optional, or even an afterthought. Where wetland avoidance is ignored, impact minimization and compensation become the default regulatory processes for wetland conservation. We suggest that decision makers and regulators need to better consider the public goods and services that flow from wetlands, and account for these losses in all compensation schemes using the best social and ecological data available. A move towards a true cost accounting approach may help address the inequitable behavior of societies where a select number of individuals reap the short-term benefits of wetland loss, while the public pays the cost for generations to come.

The literature clearly suggests that avoidance is not synonymous with preventing wetland loss. A proactive approach to protecting wetlands requires land use planning that safeguards the ecological, social, and economic value and function of wetlands, both locally and within the larger landscape. We suggest that this can be better achieved by systemically planning for wetland conservation in advance 
of development, engaging the public in the monitoring and management of wetlands, and developing a more comprehensive valuation scheme that acknowledges the complex ecological and social values of wetlands at multiple spatial scales. For meaningful areas of natural wetlands to remain in jurisdictions that rely on the wetland mitigation sequence, the public's ability to identify and communicate wetland values will need to develop commensurately with the unfolding development being leveled at wetlands, as this provides the greatest long-term hope for sustained public interest in policies that promote wetland conservation.

Acknowledgments The authors would like to thank and acknowledge the many interviewees who contributed to the research on wetland policy implementation in Alberta. We also gratefully acknowledge the many thoughtful and helpful comments provided by referee M.M. Robertson and two anonymous referees, whose contributions helped to greatly improve this manuscript. The research supporting this article was funded by the Alberta Water Research Institute and the Natural Sciences and Engineering Research Council of Canada (NSERC).

Open Access This article is distributed under the terms of the Creative Commons Attribution Noncommercial License which permits any noncommercial use, distribution, and reproduction in any medium, provided the original author(s) and source are credited.

\section{References}

Acreman MC, Blake JR, Booker DJ, Harding RJ, Reynard N, Mountford JO, Stratford CJ (2009) A simple framework for evaluating regional wetland ecohydrological response to climate change with case studies from Great Britain. Ecohydrology 2:1-17

Alberta Water Resources Commission (AWRC) (1993) Wetland management in the settled area of Alberta. Alberta Water Resources Commission, Edmonton, AB, Canada

Ando AW, Getzner M (2006) The roles of ownership, ecology, and economics in public wetland-conservation decisions. Ecol Econ 58:287-303

Armitage D (2008) Governance and the commons in a multilevel world. Int J Commons 2:7-32

Auditor General of Alberta [AGA] (2010) Report of the auditor general of Alberta April 2010. Office of the Auditor General, Edmonton, AB, Canada

Austen E, Hanson A (2007) An analysis of wetland policy in Atlantic Canada. Can Water Resour J 32:163-178

Baer WC (1997) General plan evaluation criteria: an approach to making better plans. J Am Plan Assoc 63:329-344

Bedford BL (1999) Cumulative effects on wetland landscapes: links to wetland restoration in the United States and southern Canada. Wetlands 19:775-788
BenDor T, Doyle M (2010) Planning for ecosystem service markets. J Am Plan Assoc 76:59-72

BenDor T, Brozovic N, Pallathucheril VG (2007) Assessing the socioeconomic impacts of wetland mitigation in the Chicago region. J Am Plan Assoc 73:263-282

BenDor T, Brozovic N, Pallathucheril VG (2008) The social impacts of wetland mitigation policies in the United States. J Plan Litt 22:343-357

Birol E, Cox V (2007) Using choice experiments to design wetland management programmes: the case of Severn Estuary Wetland, UK. J Environ Plan Manage 50:363-380

Boyer T, Polasky S (2004) Valuing urban wetlands: a review of non-market valuation studies. Wetlands 24:244-255

Brody SD, Highfield WE (2005) Does planning work? Testing the implementation of local environmental planning in Florida. J Am Plan Assoc 71:159-175

Brooks RP, Wardrop DH, Bishop J (2004) Assessing wetland condition on a watershed basis in the mid-Atlantic region using synoptic land-cover maps. Environ Monit Assess 94:9-22

Brooks JS, Franzen MA, Holmes CM, Grote MN, Mulder MB (2005) Testing hypotheses for the success of different conservation strategies. Conserv Biol 5:1528-1538

Brooks RP, Wardrop DH, Cole CA (2006) Inventorying and monitoring wetland condition and restoration potential on a watershed basis with examples from Spring Creek Watershed, Pennsylvania, USA. Environ Manag 38:673-687

Brown S, Veneman P (2001) Effectiveness of compensatory wetland mitigation in Massachusetts. Wetlands 21:508-518

Burgin S (2010) 'Mitigation banks' for wetland conservation: a major success or an unmitigated disaster? Wetl Ecol Manag 18:49-55

Carlsson F, Frykblom P, Liljenstolpe C (2003) Valuing wetland attributes: an application of choice experiments. Ecol Econ 47:95-103

Chavan PV, Dennet K, Marchand E (2008) Behavior of pilotscale constructed wetlands in removing nutrients and sediments under varying environmental conditions. Water, Air Soil Pollut 194:239-250

Chertok MA, Sinding K (2005) Federal jurisdiction over wetlands: "waters of the United States". In: Connolly KD, Johnson SM, Williams DR (eds) Wetlands law and policy. American Bar Association, Chicago, IL, USA, pp 59-104

Cole CA, Shafer D (2002) Section 404 wetland mitigation and permit success criteria in Pennsylvania, USA, 1986-1999. Environ Manag 30:508-515

Costanza R, Perez-Maqueo O, Martinez ML, Sutton P, Anderson SJ, Mulder K (2008) The value of coastal wetlands for hurricane protection. Ambio 37:241-248

Cowling RM, Pressey RL (2003) Introduction to systematic conservation planning in the Cape Floristic Region. Biol Conserv 112:1-13

Currin CA, Delano PC, Valdes-Weaver LM (2008) Utilization of a citizen monitoring protocol to assess the structure and function of natural and stabilized fringing salt marshes in North Carolina. Wetl Ecol Manage 16:97-118

Dahl TE, Watmough MC (2007) Current approaches to wetland status and wetlands monitoring in prairie Canada and the continental United States of America. Technical note. Can J Remote Sens 33(Suppl 1):S17-S27 
Daley DM (2007) Voluntary approaches to environmental problems: exploring the rise of nontraditional public policy. Policy Stud J 35:165-180

de Groot RS, Alkemade R, Braat L, Hein L, Willemen L (2010) Challenges in integrating the concept of ecosystem services and values in landscape planning, management and decision making. Ecol Complex 7(3):260-272

Ehrenfeld D (1981) The arrogance of humanism. Oxford University Press, New York, NY

Ehrenfeld J (2000) Defining the limits of restoration: the need for realistic goals. Restor Ecol 8:2-9

Ellis WB (2005) The EPA veto and related matters. In: Connolly KD, Johnson SM, Williams DR (eds) Wetlands law and policy. American Bar Association, Chicago, IL, pp 283-304

Environmental Law Institute (ELI) (2006) The status and character of in-lieu fee mitigation in the United States. Environmental Law Institute, Washington, DC

Environmental Law Institute (ELI) (2009) Wetland avoidance and minimization in action: perspectives from experience. Environmental Law Institute, Washington, DC

Environmental Protection Agency (EPA) (2009) Advanced identification (ADID), fact sheet 28. http://www.epa.gov/ owow/wetlands/facts/fact28.html. Accessed 29 Nov 2010

Erwin KL (2009) Wetlands and global climate change: the role of wetland restoration in a changing world. Wetl Ecol Manag 17:71-84

Fluet C, Krogman N (2009) The limits of integrated resource management for Alberta for aboriginal and environmental groups: the Northeast Slopes sustainable resource and environmental management strategy. In: Adkin LE (ed) Environmental conflict and democracy in Canada. UBC Press, Vancouver, BC, Canada, pp 123-139

Groves C (2003) Drafting a conservation blueprint: a practitioner's guide to planning for biodiversity. Island Press, Washington, DC

Hein L, van Koppen K, de Groot R, van Ierland EC (2006) Spatial scales, stakeholders and the valuation of ecosystem services. Ecol Econ 57:209-228

Hough P, Robertson M (2009) Mitigation under section 404 of the clean water act: where it comes from, what it means. Wetl Ecol Manag 17:15-33

Hudson SJ (2001) Challenges for environmental education: issues and ideas for the $21 \mathrm{st}$ century. BioScience 51:283-288

Huppes G, Midden CJ (1991) Regulations and incentives as solutions to the social dilemma in wetland management. Landsc Urban Plan 20:197-204

Hurd B, Leafy N, Jones R (1999) Relative regional vulnerability of water resources to climate change. J Am Water Resour Assoc 35:1399-1409

Johnson WC, Werner B, Guntenspergen GR, Voldseth RA, Millett B, Naugle DE, Tulbure M, Carroll R, Tracy J, Olawsky C (2010) Prairie wetland complexes as landscape functional units in a changing climate. BioScience 60:128-140

Kentula ME, Sifneos JC, Good JW, Rylko M, Kunz K (1992) Trends and patterns in Section 404 permitting requiring compensatory mitigation in Oregon and Washington, USA. Environ Manag 16:109-119
Koontz T, Thomas C (2006) What do we know and need to know about the environmental outcomes of collaborative management? Public Adm Rev 66:111-121

Krogman N (1996) Frame disputes in wetland policy. Sociol Spectr 16:371-400

Krogman N (1999) Bureaucratic slippage in organizations responsible for protecting the environment: the case of wetland regulations. Res Soc Probl Public Policy 7:163-181

Kruczynski WL (1990) Mitigation and the section 404 program: a perspective. In: Kusler JA, Kentula ME (eds) Wetland creation and restoration: the status of the science. Island Press, Washington, DC, pp 137-143

LaPeyre MK, Reams MA, Mendelssohn IA (2001) Linking actions to outcomes in wetland management: an overview of US state wetland management. Wetlands 21:66-74

Lovell ST, Sullivan WC (2006) Environmental benefits of conservation buffers in the United States: evidence, promise, and open questions. Agric Ecosyst Environ 112:249-260

Malakoff D (1998) Restored wetlands flunk real-world test. Science 280:371-372

Mann R, Goldman-Carter J (2008) Avoidance: still the best solution to the compensatory mitigation challenge. Natl Wetl Newsl July/Aug: 8-10

Margules CR, Pressey RL (2000) Systematic conservation planning. Nature 405:243-253

Massachusetts Division of Watershed Management (MDWM) (2008) Massachusetts year 2008 integrated list of waters final listing of the condition of Massachusetts' water pursuant to Sections 303(d) and 305(b) of the Clean Water Act. Division of Watershed Management Watershed Planning Program, Worcester, MA, USA. www.mass.gov/dep/water/resources/08list2.doc. Accessed 28 Nov 2010

Matthews J, Endress A (2008) Performance criteria, compliance success, and vegetation development in compensatory mitigation wetlands. Environ Manag 41:130-141

Meffe G (1992) Techno-arrogance and halfway technologies: salmon hatcheries on the Pacific coast of North America. Conserv Biol 6:350-354

Meyer S, Konisky DM (2007) Local institutions and environmental outcomes: evidence from wetlands protection in Massachusetts. Policy Stud J 35:481-502

Minns CK, Kelso JRM, Randall RG (1996) Detecting the response of fish to habitat alterations in freshwater ecosystems. Can J Fish Aquat Sci 53(Suppl 1):403-414

Mitsch WJ, Gosselink JG (2000) The value of wetlands: importance of scale and landscape setting. Ecol Econ $35: 25-33$

Mitsch WJ, Wilson RF (1996) Improving the success of wetland creation and restoration know-how, time, and selfdesign. Ecol Appl 6:77-83

Moeltner K, Woodward R (2009) Meta-functional benefit transfer for wetland valuation: making the most of small steps. Environ Resour Econ 42:89-108

Murphy J, Goldman-Carter J, Sibbing J (2009a) Avoidance avoided: how the new rule fails to adequately promote avoidance and places difficult-to-replace systems at risk. Natl Wetl Newsl March-April: 14-15 
Murphy J, Goldman-Carter J, Sibbing J (2009b) New mitigation rule promises more of the same: why the new Corps and EPA mitigation rule will fail to protect our aquatic resources adequately. Stetson Law Rev 38:311-336

National Academy of Sciences' National Research Council (NRC) (2001) Compensating for wetland losses under the clean water act. National Academy Press, Washington, DC

Nichols S (2008) Enhancing wetland protection through improved avoidance and minimization. Natl Wetl Newsl Jan/Feb: 5-7

Olsen S, Christie P (2000) What are we learning from tropical coastal management experiences? Coast Manag 28:5-18

Oscarson DB, Calhoun AJ (2007) Developing vernal pool conservation plans at the local level using citizen-scientists. Wetlands 27:80-95

Packman KA (2010) Investigation of reverse auctions for wetland restoration in Manitoba. MSc Thesis, University of Alberta, Department of Rural Economy, Edmonton, $\mathrm{AB}$, Canada

Pierce SM, Cowling RM, Knight AT, Lombard AT, Rouget M, Wolf T (2005) Systematic conservation planning products for land-use planning: interpretation for implementation. Biol Conserv 125:441-458

Pifher MT (2005) The section 404(b)(1) guidelines and practicable alternatives analysis. In: Connolly KD, Johnson SM, Williams DR (eds) Wetlands law and policy. American Bar Association, Chicago, IL, pp 221-252

Pressey RL, Bottrill MC (2008) Optimism, threats, and the evolution of systematic conservation planning. Conserv Biol 22:1340-1345

Pruetz R (2009) What makes transfer of development rights work: success factors from research and practice. J Am Plan Assoc 75:78-87

Race MS, Fonseca MS (1996) Fixing compensatory mitigation: what will it take? Ecol Appl 6:94-101

Reed M (2008) Stakeholder participation for environmental management: a literature review. Biol Conserv 141:2417-2431

Reiss KC, Hernandez E, Brown MT (2009) Evaluation of permit success in wetland mitigation banking: a Florida case study. Wetlands 29:907-918

Roberts L (1993) Wetlands trading is a loser's game, say ecologists. Science 260:1890-1892

Robertson MM (2000) No net loss: wetland restoration and the incomplete capitalization of nature. Antipode 32:463-493

Robertson M, Hayden N (2008) Evaluation of a market in wetland credits: entrepreneurial wetland banking in Chicago. Conserv Biol 22(3):636-646

Rubec CDA, Hanson AR (2008) Wetland mitigation and compensation: Canadian experience. Wetl Ecol Manage 17(1):3-14

Ruhl JB, Salzman J (2006) The effects of wetland mitigation banking on people. FSU College of Law, Public Law Research Paper No. 179, Tallahassee, FL, USA. http://papers.ssrn.com/sol3/ papers.cfm?abstract_id=878331. Accessed 6 Dec 2009

Ruhl JB, Salzman J, Goodman I (2009) Implementing the new ecosystem services mandate of the Section 404 compensatory mitigation program - a catalyst for advancing science and policy. Stetson Law Rev 38:251-272
Salzman J, Ruhl JB (2005) No net loss-instrument of choice in wetlands protection. Duke Law School Science, Technology and Innovation Research Paper Series, Research Paper No. 1, September 2005, Durham, NC, USA. http://ssrn.com/abstract=796771. Accessed 26 May 2010

Sarkar S, Pressey RL, Faith DP, Margules CR, Fuller T, Stoms DM, Moffett A, Wilson KA, Williams KJ, Williams PH, Andelman S (2006) Biodiversity conservation planning tools: present status and challenges for the future. Annu Rev Environ Resour 31:123-159

Schulte-Hostedde BD, Walters D, Powell C, Shrubsole D (2007) Wetland management: an analysis of past practice and recent policy changes in Ontario. J Environ Manag 82(1):83-94

Seasons M (2003) Monitoring and evaluation in municipal planning. J Am Plan Assoc 69:430-440

Sharpe A, Conrad CS (2006) Community based ecological monitoring in Nova Scotia: challenges and opportunities. Environ Monit Assess 113:395-409

Simenstad C, Reed D, Ford M (2006) When is restoration not? Incorporating landscape-scale processes to restore selfsustaining ecosystems in coastal wetland restoration. Ecol Eng 26:27-39

Spieles DJ (2005) Vegetation development in created, restored, and enhanced mitigation wetland banks of the United States. Wetlands 25:51-63

Stanturf JA, Schoenholtz SH, Schweitzer CJ, Shepard JP (2001) Achieving restoration success: myths in bottomland hardwood forests. Restor Ecol 9:189-200

Stein ED, Ambrose R (1998) A rapid impact assessment method for use in a regulatory context. Wetlands 18:379-392

Stokstad E (2008) Environmental regulation: new rule on saving wetlands push the limits of science. Science 320:162-163

Taylor WE, Geoffroy KL (2005) General and nationwide permits. In: Connolly KD, Johnson SM, Williams DR (eds) Wetlands law and policy. American Bar Association, Chicago, IL, pp 151-190

ten Kate K, Bishop J, Bayon R (2004) Biodiversity offsets: views, experience, and the business case. International Union for Conservation of Nature and Natural Resources and Insight Investment Management (Global) Ltd, London

Turner RK, van den Bergh JCJM, Soderqvist T, Barendregt A, van der Straaten J, Maltby E, van Ierland EC (2000) Ecological-economic analysis of wetlands: scientific integration for management and policy. Ecol Econ 35:7-23

Turner R, Redmond A, Zedler JB (2001) Count it by acre or function-mitigation adds up to net loss of wetlands. Natl Wetl Newsl 23:5-16

United States Government Accountability Office (GAO) (2005) Wetlands protection: corps of engineers does not have an effective oversight approach to ensure that compensatory mitigation is occurring. Report GOA 05-898, Washington, DC

Walters D, Shrubsole D (2005) Assessing efforts to mitigate the impacts of drainage on wetlands in Ontario, Canada. Can Geogr 49:155-171 
Wenig M (2006) The sleeping giant of watershed protection. Law Now April/May 2006. http://www.pekisko.ca/ docs/D_060501_SleepingGiant.pdf. Accessed 26 May 2010

Wenig M (2010) Understanding local Albertans' role in watershed planning-will the real blueprint please step forward? CIRL Occasional paper \#28. Canadian Institute of Resources Law, Calgary, AB

Wilkinson J, Thompson J (2006) 2005 status report on compensatory mitigation in the United States. Environmental Law Institute, Washington, DC

Williams DR, Connolly KD (2005) Federal wetlands regulation: an overview. In: Connolly $\mathrm{KD}$, Johnson SM,
Williams DR (eds) Wetlands law and policy. American Bar Association, Chicago, IL, pp 1-26

Yocom TG, Leidy RA, Morris CA (1989) Wetlands protection through impact avoidance: a discussion of the 404(b)(1) alternatives analysis. Wetlands 9:283-297

Zedler JB (1996) Ecological issues in wetland mitigation: an introduction to the forum. Ecol Appl 6:33-37

Zedler JB, Callaway JC (1999) Tracking wetland restoration: do mitigation sites follow desired trajectories? Restor Ecol 7(1):69-73

Zedler JB, Kercher S (2005) Wetland resources: status, trends, ecosystem services, and restorability. Annu Rev Environ Resour 30:39-74 